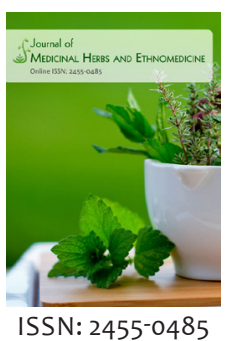

Received: April 19, 2020 Accepted: June 13, 2020 Published: June 20, 2020

*Corresponding Author: Suhita Chakrabarty Email: saujanendra@gmail. com

\section{Ethnoveterinary practice followed by Santhal tribes to treat foot and mouth diseases of livestock in Ghatshila Block, Jharkhand, India}

\author{
Saujanendra Swain ${ }^{1 *}$, Sujoy Bhattacharya², Suhita Chakrabarty³ \\ 'National Resource Person, National Rural Livelihoods Mission, Govt. of India, New Delhi, India, \\ ${ }^{2}$ Regional Head, Rural Development Agency, Ghatsila, East Singhbhum district, Jharkhand, India, \\ ${ }^{3}$ Mission Manager- Farm, Livelihoods, National Rural Livelihoods Mission, Govt. of India, New Delhi, India
}

\begin{abstract}
An ethnoveterinary study was conducted among the Santhal tribes residing in Ghatshila block of East Singhbhum district in Jharkhand state to document the ethno-medicinal plants, those are used to treat the foot and mouth diseases of livestock. The ethnoveterinary knowledge was documented from the traditional healthcare practitioners in eight villages of the block. The study has resulted use of four plant species belonging to 4 different families to treat foot and mouth diseases among livestock. Out of the four plant species, three are trees and one is shrub. The paper describes the plants used for ethno-veterinary practices to treat food and mouth diseases of livestock with botanical names, family, local names, english name, parts used, mode of preparation and administration of herbal drugs.
\end{abstract}

Keywords: Ethno-veterinary; plants; tribes; foot and mouth diseases; livestock

\section{INTRODUCTION}

Ethnoveterinary medicine, deals with traditional animal health care which encompasses the knowledge, skills, methods, practices and beliefs about animal health care. A broader survey has shown that more than $80 \%$ of the tribal populations are still depend on traditional medicines for their animal health practices; of which $95 \%$ are of plant origin [1]. In spite of the clinical agents developed by the pharmaceutical industry, traditional indigenous phototherapy is still practiced in many rural areas for human and livestock ailments, using strictly guarded treatments handed from generation to generation [2]. India has a long history in the use of herbal medicine for animal treatment [3]. The tribal are as for themselves never depend on the distant government veterinary hospitals for the obvious economic reasons or the limitation of resources, and lean to the traditional herbal remedial measures for animals. [4].

The ethnoveterinary medicine is easily available, cheap and effective, cures many diseases and causes no side effects. Besides, no complicated technology is required for its preparation. The tribal people have been using this traditional system for a very long time. They have acquired this valuable knowledge from experience, trial and error methods. This knowledge has passed down from one generation to next generation by word of mouth [5].

The best reasons for using traditional methods of treating veterinary diseases are: (a) cost effectiveness of the developed technology (b) no side effects noted (c) lack of accessibility to modern veterinary facilities and treatments. These reasons offer an inclined response over the field of ethnoveterinary research and development [6]. It also has now been fully realized that "many of traditional systems are sustainable, time tested and are in harmony with nature" Therefore, a serious attempt to revisit the significance of Veterinary Ayurveda is a recent development for livestock healthcare, in India and world over [7].

Jharkhand is a tribal dominated state of India. The Santhal tribe is one of the most dominant tribes of the state. Traditional method of veterinary treatment using plants are predominant in tribal and rural areas of Jharkhand state. Santhal tribes are more social and they live in rural areas along with other castes besides their preferred habitats near forests. They have their own age-old material culture and have a clear understanding of the forest and forest resources. They use a number of wild plant species not only to meet their daily needs but also for primary healthcare of human and livestock [8]. 
This paper is an account of such herbal practices in animal health care system followed up by Santhal tribe of Ghatshila block in East Singhbhum district of Jharkhand state, India (Figure-1)

\section{MATERIALS \& METHODS}

The study was conducted in eight villages under three Gram Panchayats of Ghatshila block, East-Singhbhum district of Jharkhand state. The villages were selected based on the dominance of Santhal tribe population. Four-day field visits were conducted to villages with the help of staff members of RDA (NGO) located in Ghatshila. Interviews were organised with the traditional healthcare practitioners, locally known as Ojha, through a structured questionnaire to document the ethnoveterinary practices. Plant species were collected from forest located near to the villages. The method of preparation of herbal drugs and the process involved in administration to livestock were also documented. These plant species were identified at Regional Plant Resource Centre, Bhubaneswar, Odisha for proper botanical name and their family with the help of renowned plant taxonomist. Photographs of each of the plant species were taken and digital herbariums were prepared to describe the plant species in detail. Herbariums of each plant species was prepared adopting the standard herbarium

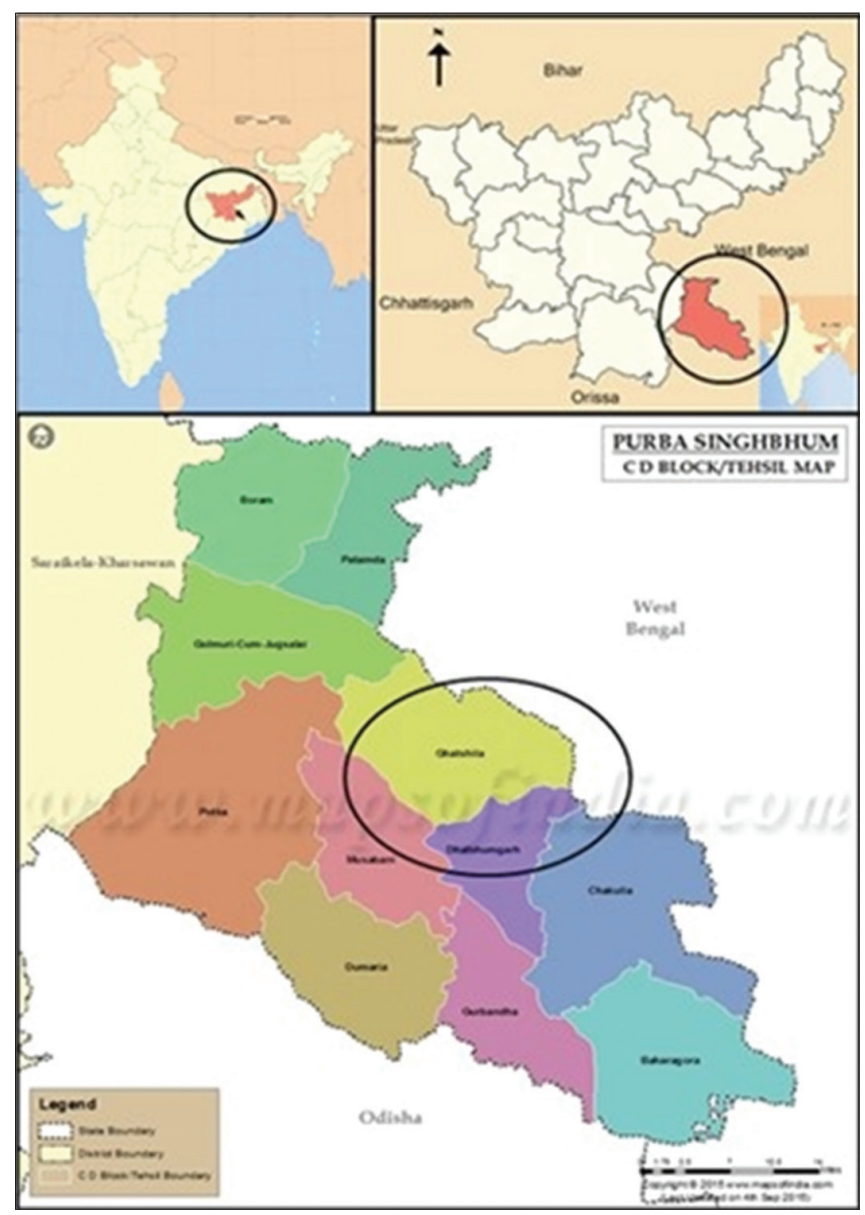

Figure 1: Map of India showing Jharkhand State, East-Singhbhum district and Ghatshila block techniques and are kept in safe custody at RDA office, Ghatshila for future reference. Focus group discussions were conducted with age old men and women to validate the information documented.

\section{Study Area}

Ghatshila is a community development block located in East Singhbhum district of Jharkhand state in India. It is located between $22.60^{\circ} \mathrm{N}$ Latitude and $86.4^{\circ} \mathrm{E}$ Longitude with an average elecvation of 103 metre. The block was established during the year 1962. The block is situated in the riverbank of Subernarekha river with a distance of $45 \mathrm{Km}$ of the district headquarter. Ghatshila block consist of 176 villages and 25 -gram panchayats. The total population of the block is 129,905 as per 2011 census of India. The sex ratio of Ghatshila block is 971 . Of the total population, $31.3 \%$ lives in urban areas whereas $68.7 \%$ population lives in rural areas. The total Schedule Tribe population is 54,663 , which constitutes about $42.07 \%$ of the total population. The literacy rate of the block is $70.72 \%$. The major tribes found in this region are Santhal, Munda, Oraon, Sabar and Bhumij. Out of the total geographical area of the block, nearly $22 \%$ are under forest cover and the forest type found in this region is mostly mixed dry deciduous.

\section{RESULTS \& DISCUSSION}

Due to the poor public services for healthcare maintenance for livestock in remote areas of the Ghatshila block, the tribal people have adopted traditional way of treating their livestock through plant-based medicines usually prepared by local Ojha's (ethno-veterinarian) based on their traditional knowledge. Their herbal drugs were very effective to treat common diseases like diarrhoea, skin diseases, and foot and mouth disease.

The study documented four plant species those are being used to treat food and mouth diseases of the livestock. The list of plant species documented during the study are presented in Table-l and the photographs of the documented plant species are presented in Figure-2.

Out of the four plants, three are tree species, where as one is shrub. All these four genera are belonging to four different families. The families are Anacardiaceae, Bignoniaceae, Caesalpiniaceae and Rubiaceae. In most of the cases the fruit and seeds are being is used but in one case the bark is used (Table-2).

The method of preparation of the herbal drug and its administration to treat the food and mouth diseases through the use of the above mentioned four plants are as follows. Three seeds of Semecarpus anacardium, 100-gram bark of Oroxylum indicum, one fruit of Benkara malabarica, 100-gram seed coat of Cassia fistula and one whole piece of garlic were grinded together to make powder. This powder will be mixed with 5 -gram salt and $20 \mathrm{ml}$ of honey to make a paste. This paste has to be applied in the affected areas three times in a day and one small portion has to be orally administered one time in a day. 
Table 1: List of plant species used to treat foot and mouth diseases by the tribal people of Jharkhand

\begin{tabular}{|c|c|c|c|c|}
\hline SI. Local name & English name & Botanical name & Family & Habit \\
\hline 1. Gurmohan & - & Benkara malabarica (Lam) Tirveng. & Rubiaceae & Shrub \\
\hline 2. Amaltas & Golden Shower Tree & Cassia fistula L. & Caesalpiniaceae & Tree \\
\hline 3. Bhalusakti & Broken Bones Tree & Oroxylum indicum (L.) Kurz & Bignoniaceae & Tree \\
\hline 4. Bhela & Marking nut & Semecarpus anacardium L.f. & Anacardiaceae & Tree \\
\hline
\end{tabular}

Table 2: Plant parts used for treating foot \& mouth diseases

\begin{tabular}{lll}
\hline SI. & Botanical Name & Parts used \\
\hline 1. & Benkara malabarica (Lam) Tirveng. & Fruit \\
2. & Cassia fistula L. & Seed Coat \\
3. & Oroxylum indicum (L.) Kurz & Bark \\
4. & Semicarpus anacardium L.f. & Fruit \\
\hline
\end{tabular}
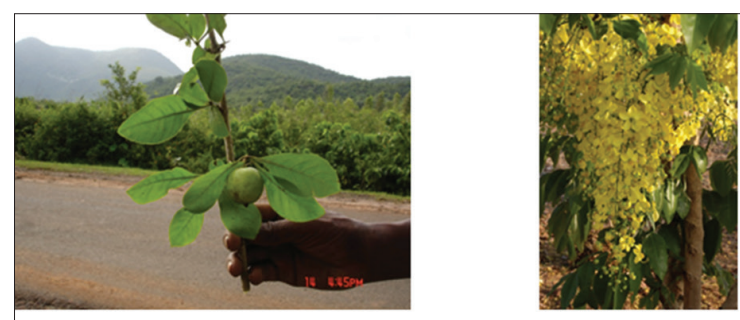

Benkara malabarica (Lam) Triveng.

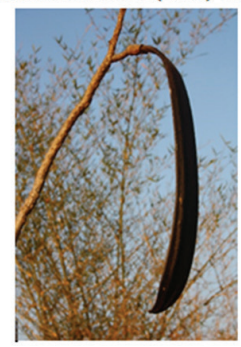

Oroxylum Indicum (L.) Kurz

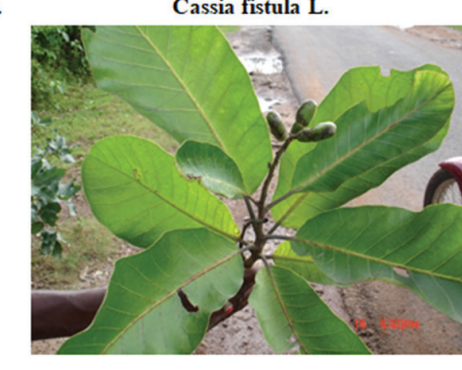

Semecarpus anacardium L.f.

Figure 2: Photographs of the plant species documented

Every day, fresh paste has to be prepared. The process has to be continued for a week for complete treatment of the foot and mouth diseases. During the discussion it was found out that the plant Benkara malabarica is also used to treat skin diseases.

\section{CONCLUSION}

It was observed during the study that most of the traditional healthcare practitioners (Ojha) are reluctant to share the method of preparation of the ethnoveterinary drugs due to their belief that, if they disclose, the efficacy of the practice will go away. They normally pass on this secret information to their children through oral communications. There is a danger of extinction of these traditional knowledge systems due to oral transmission. It is therefore necessary to document these traditional knowledge systems on ethnoveterinary practices, so that the knowledge can be preserved and utilized for further research and use. Currently the younger generations in Santhal community does not have any knowledge and practice of ethnoveterinary care, therefore, it is necessary to build the skill and capacity of these youths on ethno-veterinary practices. There is an urgent need to validate this traditional knowledge on animal healthcare possess by the tribal people and herbal drugs for veterinary care to be developed in a benefit sharing mechanisms with the tribal people. It is also necessary to recognise and reward the traditional healthcare practitioners prevailing in tribal communities.

Apart from this, conservation and proper management of local vegetation is required for sustainable existence of the tribe in future. According to IUCN red list data, Oroxylum indicum is an endangered species [9]. There is an urgent need to conserve and propagate the endangered species namely Oroxylum indicum for future use by these tribal communities.

\section{ACKNOWLEDGEMENT}

The authors would like to thank National Rural Livelihoods Mission (NRLM), Ministry of Rural Development, Govt. of India for providing financial support to carryout the study under its Mahila Kisan Shashktikaran Pariyojana programme. Our sincere thanks go to Mr. Alok De, Lead- Farm Livelihoods of NRLM for his constant encouragement, guidance and moral support for documentation of traditional knowledge on use of plants for treating both plant and animal diseases. We pay our sincere gratitude to the staffs and scholars of RDA (NGO) located at Ghatshila for their support in carrying out this study and field guidance. Our heartfelt thanks go to the traditional healthcare practitioners, tribal women and men of Ghatshila block, who have contributed and shared their traditional knowledge system selflessly with us.

\section{REFERENCES}

1. Pragada PM, Rao GMN. Ethnoveterinary medicinal practices in tribal regions of Andhra Pradesh, India. Bangladesh J. Plant Taxon, 2012; 19(1): 7-16

2. Mahmud S, Shah NH. Use of aquatic and marshy plants in ethnoveterinary practices by tribals and rural people of Jammu province, (J\&K), India. International Journal of Plant Sciences. 2009; 4(2): 471-474

3. Sasaki M.Traditional Veterinary medicine in Aisa. Medicinal and Aromatic plants in Asia: Breeding and Improvement. Oxford and IBH publishing co. Pvt. Ltd. New Delhi; 1995.

4. Mallik BK, Panda T, Padhy RN. Ethnoveterinary practices of aborigine tribes in Odisha, India. Asian Pacific Journal of Tropical Biomedicine, 2012; S:1520-S1525

5. Sikarwar RLS, Kumar Vivek. Ethnoveterinary knowledge and practices prevalent among the tribals of central India. Journal of Natural Remedies, 2012; 5 (2): 147-152

6. Banumathi B, Vaseeharan B. A Report on Medicinal Plants Used in Ethno Veterinary Practices of Toda Tribe in the Nilgiri Hills. Journal of Veterinary Science \& Technology, 2015; 6(5): 1-6

7. Kohli RN. Ethno-veterinary Medicine: A Concept for Sustainable Livestock Production. National Academy of Veterinary Sciences (India), New Delhi, 2015.

8. Mandal AK, Dutta BB. Ethnoveterinary practices by Santhal tribes in Jamtara districts of Jharkhand. Ecoinformatics. Daya Publishing House, New Delhi, 2008. 
9. Kumari P, Joshi GC, Tewari LM. Biodiversity Status, Distribution and Use Pattern of Some Ethno-Medicinal Plants. International Journal of Conservation Science, 2012; 3(4): 309-318

10. Balakrishnan Nair MN, Punniamurthy N, Kumar S. Ethno-veterinary Practices for Animal Health and the Associated Medicinal Plants from 24 Locations in 10 States of India. Journal of Veterinary Sciences, 2017; 3(1): 25-34

11. Deora GS, Rathore MS. Ethno-Veterinary Medicine (EVM) and Traditional Practices in Animal Health Care System (AHCS) in the Southern Part of Rajasthan- India. International Journal of Ayurvedic and Herbal Medicine, 2017; 7 (4): 2746-2751

12. Kumar AT, Singh R, Panwa PS. Ancient Indian Literature on Animal Housing and Health Corroborated by Modern Literature. Asian AgriHistory, 2015; 19(4): 317-328

13. Mairh AK, Mishra PK. Ethno-Veterinary Wisdom of Birhore Tribes of Jharkhand. International Journal of Bioassays, 2015; 4(2): 3686-3687.

14. Meena KL. Some Traditional Ethno-Veterinary Plants of District Pratapgarh, Rajasthan, India. American Journal of Ethnomedicine,2014; 1(6): 393-401 